\title{
Evaluating the rate of atmospheric dust deposition in Isfahan city
}

\author{
Faranak MOTAMEDI ${ }^{1}$, Mozhgan Ahmadi NADOUSHAN ${ }^{1,2 *}$ and Ahmad JALALIAN ${ }^{3}$ \\ ${ }^{1}$ Department of Environmental Sciences, Isfahan (Khorasgan) Branch, Islamic Azad University, Isfahan, Iran. \\ ${ }^{2}$ Department of Environmental Sciences, Waste and Wastewater Research Center, Isfahan (Khorasgan) Branch, Islamic \\ Azad University, Isfahan, Iran \\ ${ }^{3}$ Desertification, Combating Desertification and Dust storm stabilization research center, Isfahan (Khorasgan) Branch, \\ Islamic Azad University, Isfahan, Iran. \\ *Corresponding author:m.ahmadi@khuisf.ac.ir
}

Received: June 19, 2019; accepted: December 11, 2020

\section{RESUMEN}

El depósito de polvo ocurre extensamente en áreas áridas y semiáridas. Las partículas de polvo tienen una alta capacidad de adsorción y por lo tanto un alto potencial contaminante. El presente estudio investiga las variaciones estacionales y espaciales en la tasa de depósito de polvo atmosférico (DDR) y la concentración de metales pesados transportados por el polvo en la parte oriental de Isfahan y en la llanura de Segzi, ubicada en la parte central de Irán. Se recolectaron muestras de polvo de nueve sitios diferentes mensualmente desde diciembre de 2016 hasta septiembre de 2017 utilizando bandejas de vidrio. Se midieron las concentraciones totales de $\mathrm{Pb}$ y $\mathrm{Zn}$. Se registraron las concentraciones más bajas de $\mathrm{Pb}$ con $16.95 \pm 25.21 \mathrm{mg} \mathrm{kg}^{-1}$ y de Zn con $2.34 \pm 0.80 \mathrm{mg} \mathrm{kg}^{-1}$. El valor más bajo de DDR estacional $\left(0.70 \pm 0.1{\text { ton } \mathrm{km}^{-2} \text { temporada }}^{-1}\right)$ se observó en el invierno debido a la baja precipitación y el valor más alto $\left(40.80 \pm 0.1\right.$ ton $\mathrm{km}^{-2}$ temporada $\left.{ }^{-1}\right)$ se registró en el verano. La distribución espacial de $\mathrm{Pb}$ y $\mathrm{Zn}$ en el polvo siguió casi la misma tendencia y las concentraciones más altas se observaron en las zonas occidentales del área de estudio. Combustibles fósiles, tráfico y actividades industriales son los factores antropogénicos más importantes que contribuyen a los metales pesados transportados por el polvo en el área de estudio.

\begin{abstract}
Dust deposition occurs extensively in arid and semi-arid areas. Dust particles have a high adsorption capacity and therefore high pollution potential. The present study investigates seasonal and spatial variations in atmospheric dust deposition rate (DDR) and the concentration of dust-borne heavy metals in the eastern part of Isfahan as well as Segzi plain located in the central part of Iran. Dust samples were collected from nine different sites on a monthly basis from December 2016 to September 2017 using glass trays. The total concentrations of $\mathrm{Pb}$ and $\mathrm{Zn}$ were measured. The lowest concentrations of $\mathrm{Pb}$ with $16.95 \pm 25.21 \mathrm{mg} \mathrm{kg}^{-1}$ and $\mathrm{Zn}$ with $2.34 \pm 0.80 \mathrm{mg} \mathrm{kg}^{-1}$ were recorded. The lowest value of seasonal DDR $\left(0.7 \pm 0.1\right.$ ton $\mathrm{km}^{-2}$ season $\left.^{-1}\right)$ was observed in the winter due to low amount of precipitation, and the highest value $\left(40.8 \pm 0.1\right.$ ton $\mathrm{km}^{-2}$ season $\left.{ }^{-1}\right)$ was recorded in the summer. Spatial distribution of dust-borne $\mathrm{Pb}$ and $\mathrm{Zn}$ followed almost the same trend and the highest concentrations were observed in the western parts of the study area. It seems that fossil fuel, traffic, and industrial activities are the most important anthropogenic factors contributing to dust-borne heavy metals in the study area.
\end{abstract}

Keywords: Dust, Deposition rate, Heavy metals, $\mathrm{Zn}, \mathrm{Pb}$. 


\section{Introduction}

Currently, more than $50 \%$ of the world population are city dwellers. Considering the rapid urbanization rate, $70 \%$ of the world population will be residing in cities by 2050 . Human activities pertaining to industrialization and urbanism are predominantly concentrated in urban areas, especially in Africa and Asia (Li et al., 2016). Atmospheric pollution is a serious issue in large cities (Kidak, 2017). Rapid population growth, urbanization, and industrial activities are the main sources of air pollutants, particularly heavy metals, in urban areas. Over the last four decades, many cities in Iran have faced large-scale urbanization (Jahandari, 2020), with associated traffic and industrial activities, and exposing the population to hazardous pollutants. Awareness and air pollution control is very important but difficult.

In addition, dust events may contribute to air pollution in arid, semiarid and desert areas. Atmospheric dust events result from the mobility of Eolian particles in central and eastern Asia. Historically, atmospheric dust had affected stretches of the silk road which connected Asia and Europe. Certain landscape types, such as playas, are susceptible to wind erosion and probably one of the major sources of dust in arid areas (Ziyaee et al., 2018). Surface soil is another source of dust (Mirzaei Aminiyan et al., 2017). Atmospheric dust impacts the global radiation balance and regional air quality in both remote and urban areas. Various factors contribute to dust fallout and deposition, which control the spatial distribution of atmospheric dust. They include surface roughness, vegetation, soil properties (for example, humidity, texture, roughness, composition and mineralogy) and topographic properties. Atmospheric dust deposition plays a role in soil formation and biological variation in arid and semi-arid regions. Drought could also have an important impact on dust deposition rate (Ta et al., 2004).

Atmospheric dust affects urban air quality, public health and also impacts structures and monuments. High dust concentrations can potentially lead to allergies, pneumonia, asthma and eye irritation (Malakootian et al., 2013). Dust transported to urban areas will mix with the particulate matter originated by anthropogenic activities, such as burning coal, oil, wood and waste, and road traffic emissions (Farkas \& Török, 2019).
Atmospheric dust may act as reaction carrier and substrate for other pollutants, particularly in urban and industrial areas. Industries such as mining and smelting, manufacturing of non-ferrous metals, construction projects, as well as fossil fuel combustion and vehicular traffic can generate heavy metals, which are toxic and even carcinogenic. Heavy metals are more concentrated in atmospheric particles in urban areas compared with rural areas (Wan et al., 2016). Heavy metals emitted in urban areas affected by dust, may adhere to dust particles, which results in heavy metals getting non-resistant; it can also lead to potential biologic activity (Jalili et al., 2015). Dust-borne metals may enter the body through inhalation and ingestion or physical contact. Some of the heavy metals can be absorbed and accumulate in tissues and result in adverse physiologic effects (Abdul Wahab et al., 2012). Moreover, it has been shown that heavy metals may impede the working of central nervous system, urinary system and reproductive system (Norouzi et al., 2017). For example, high lead $(\mathrm{Pb})$ levels in children's blood may harm their central nervous system and skeleton (Han et al., 2017). Traffic is usually the major source of atmospheric lead, caused by gas emission from vehicles (especially leaded gasoline), and wear and tear of tires, brakes and other parts (Lin et al., 2016); similar sources emit copper $(\mathrm{Cu})$ and zinc $(\mathrm{Zn})$ and other heavy metals (Doabi et al., 2017).

A number of studies have been conducted to assess dust deposition rate (DDR) and its physical, chemical and mineralogical properties in Iran. Nevertheless, DDR has been measured directly at only few sites and valid data are lacking in many sites around the world (Zhang et al., 2017). Moreover, seasonal and spatial variations in DDR have not been investigated properly.

Aghasi et al. (2019) studied the relationship between soil characteristics and DDR in Gavkhouni swamp sub-basin located in Central Iran. Results showed that particle size distribution of surface soil, especially sand content is an important factor which affects seasonal and annual DDR (Aghasi et al., 2019). Doabi et al. (2017) used 98 samples of atmospheric dust which were collected during the spring (T1) and summer (T2) of 2013 from urban and suburban locations in Kermanshah province, and analyzed them for $\mathrm{Zn}, \mathrm{Cu}, \mathrm{Ni}, \mathrm{Cr}, \mathrm{Mn}$, and $\mathrm{Fe}$ total concentrations. The contamination levels of heavy 
metals were assessed based on enrichment factor (EF), geo-accumulation index (Igeo), and ecological risk (RI). The analysis of EF revealed moderate enrichments for $\mathrm{Mn}$ and $\mathrm{Cr}$, and significant enrichments for $\mathrm{Zn}, \mathrm{Cu}$, and $\mathrm{Ni}$ in $\mathrm{T} 1$ and $\mathrm{T} 2$, and similarly in urban and suburban areas. Based on Igeo index, the levels of $\mathrm{Mn}$ and Fe were classified as uncontaminated, while $\mathrm{Zn}, \mathrm{Cu}, \mathrm{Ni}$, and $\mathrm{Cr}$ levels were assessed to have moderate contamination in $\mathrm{T} 1$ and $\mathrm{T} 2$, and similarly in urban and suburban areas. The values of RI showed a low level of heavy metals pollution. Zgłobicki et al. (2019) assessed changes in heavy metals in particulate matter at street level in Lublin, Poland in the years 2013 and 2018. The sample collection sites were located within streets with a different intensity of motor traffic. $\mathrm{Cd}, \mathrm{Cr}, \mathrm{Cu}, \mathrm{Ni}, \mathrm{Pb}$ and $\mathrm{Zn}$ concentrations were determined. Results showed that street dust in Lublin did not show contamination with $\mathrm{Cr}, \mathrm{Ni}$ and $\mathrm{Pb}$ (Zgłobicki et al., 2019).

Malakootian et al. (2013) evaluated the dust fall events in Kerman city based on sampling sites located in seven spots of the city. Forty-two dust fall samples were monthly collected during 6 months. Dust fall concentrations were analyzed as a function of times, locations and meteorological parameters. No significant association was observed between variables such as temperature, humidity, wind speed and dust concentration, whereas a significant association was found between precipitation variable and dust concentration. One-Way ANOVA Test showed a meaningful difference between mean of the TDF values in different stations and sampling period.

Isfahan is a populated city located in the central part of Iran with heavy traffic and various industrial plants, ranked as the second industrial region in Iran. As a result, it is one of the most polluted cities in the country. Moreover, desert areas in the eastern and northern skirts of Isfahan are the sources of several dust events each year (Norouzi et al., 2017). In spite of the importance of conducting research in this regard, no comprehensive study has been reported to date on the spatial and temporal variations in dust deposition rate and its properties in this area. Gaining insight into chemical properties of atmospheric dust deposition and the sources of heavy metals in dust is important in that such knowledge can help not only control atmospheric pollution but also develop appropriate strategies to reduce pollution.
The objectives of the present study are (1) investigating spatial and temporal variables in dust deposition rate in the urban, rural and desert areas, (2) determining the effect of seasonal and spatial variations on the concentration of dust-borne heavy metals (lead and zinc).

\section{Materials and Methods}

\subsection{Study area}

The area under investigation is located in the eastern part of Isfahan province, between $30^{\circ} 4^{\prime}$ to $27^{\circ} 34^{\prime} \mathrm{N}$ and $36^{\circ} 49^{\prime}$ to $31^{\circ} 55^{\prime} \mathrm{E}$ which is about 107044 square kilometers in area and comprises $6.25 \%$ of Iran's total area. The study area includes the city of Isfahan which is the capital of this province and is ranked as the second industrial and third populated city in Iran. The eastern and northern parts include deserts and rural regions with small towns (Norouzi et al., 2017). The study area is in the central Iranian plateau with an average elevation of 1580 meters above the sea level and is characterized with dry climate and hot summers.

There are different industrial sites in Isfahan, including Mobarakeh Steel Company, the largest steel company of Iran, and Esfahan Steel Company located in the west and southwest of Isfahan. Moreover, an oil refinery, a petrochemical company and a number of other large and small companies are located close to the city (Fig. 1).
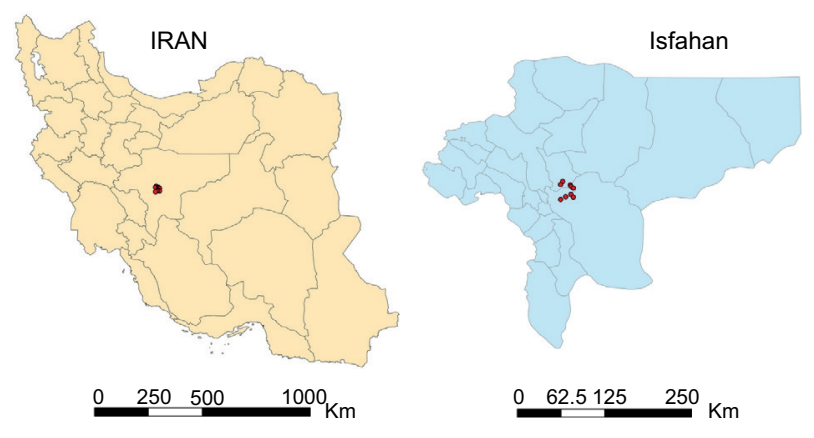

Fig 1. The location of study area.

\subsection{Dust sampling}

Dust samples were taken at nine sites distributed across the area under investigation. The trap used consisted of a flat glass sheet of $1 \times 1$ meter. Opening 
on its top was a 2 square millimeters plastic mesh fixed on the glass using eight bolts. To avoid deposited particles being washed out in seasons with precipitation, a glass edge with the height of 2 centimeters was attached around the glass so that, in case of rainfall, the raindrops on the surface of the glass could run over the glass through a small outlet covered with sponge. The sponge was used to prevent deposited particles running out. The trap was selected inspired by studies conducted by Menéndez et al. (2017), Hojati et al. (2007), Norouzi et al. (2015), and Ziyaee et al. (2018). At each dust sampling site, one-story buildings were chosen and a glass trap was placed on the roof of each building above the ground level so that walls or any other barriers could not affect it. The height chosen made it possible for the deposited dust on the surface of the traps not to be affected by wind processes closes to ground level. Moreover, as the height was not too much, the concentration of the collected dust was approximately close to the amount inhaled by people. Dust samples on the surface of each glass tray were collected using a spatula at the end of each month from 21 December 2016 to 23 September 2017. In the laboratory, dust samples were passed through a two-millimeter sieve and were weighed. After each sampling, trays were carefully washed with distilled water.

\subsection{Heavy metals analysis}

The total elemental composition of the dust samples was determined after acid digestion. One gram of the sample was digested using 10 milliliters of HNO3 and 10 milliliters of $\mathrm{HCIO} 4$ at $210^{\circ} \mathrm{C}$ for 90 minutes. After cooling, $0.1 \mathrm{~N} \mathrm{HCl}$ was added to fill the $100 \mathrm{ml}$ volumetric flask (Risser and Baker, 1990). Samples prepared this way were passed through a filter paper and the extract was analyzed to determine the concentration of $\mathrm{Zn}$ and $\mathrm{Pb}$ using plasma mass spectrometer (Agilent Technologies, ICP-MS). Thereby, the total concentrations of $\mathrm{Zn}$ and $\mathrm{Pb}$ were measured.

\subsection{Data Analysis}

For each sampling site, dust deposition rate (DDR) was calculated based on sample weight, area of the trapped dust (square meter), and the period of time at which the dust was collected (one month). The mean DDR was calculated monthly in each season. All statistical analyses including Duncan (for determining the significance of the differences among mean values) and correlation analysis were done using SAS 9.4 (The Texas Medical Center Library, 2019) (Fig. 2).

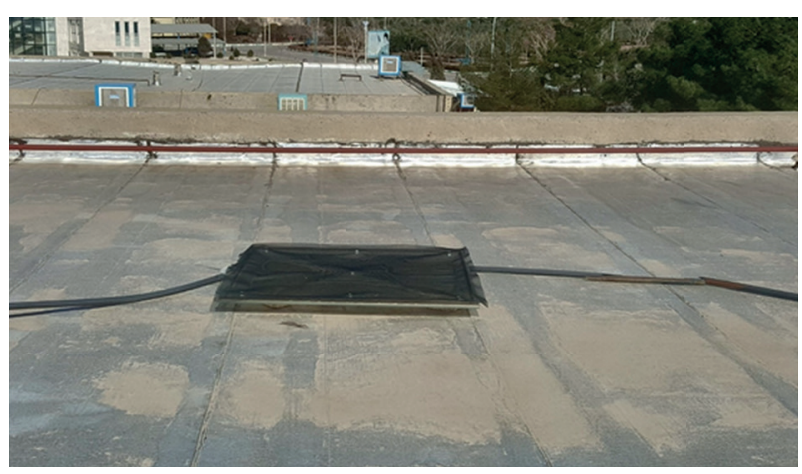

Fig 2. Glass tray used in this study.

\section{Results and Discussion}

3.1 Comparing the concentrations of $\mathrm{Zn}$ and $\mathrm{Pb}$ in different stations

Zn concentration did not reveal significant differences in different stations. However, $\mathrm{Pb}$ concentrations were indicative of a significant difference between Parvaneh Rural District station (I) and Islamic Azad University, Khorasgan branch $(\mathrm{E})$ station $(\mathrm{P}<0.05)$; however, other stations did not show a significant difference $(\mathrm{P}>0.05)$ (Table I). Variance analysis of heavy metals in different stations showed that the highest concentrations of $\mathrm{Zn}$ and $\mathrm{Pb}$ were observed in the station of Khorasgan University (Table II).

Table I. Comparison of the mean values of heavy metals in different stations

\begin{tabular}{ccc}
\hline Heavy metal & DF & F Value \\
\hline $\mathrm{Pb}$ & 8 & $1.30^{\mathrm{N} . S}$ \\
$\mathrm{Zn}$ & 8 & $1.61^{\mathrm{N} . S}$ \\
\hline
\end{tabular}

\subsection{Comparing the concentrations of $\mathrm{Zn}$ and $\mathrm{Pb}$ in different seasons}

Zn concentration did not show a significant difference in the three sampling seasons; however, there 
Table II. Variance analysis of heavy metals in different stations.

\begin{tabular}{lcc}
\hline Station & $\mathrm{Zn}\left(\mathrm{mg} \mathrm{kg}^{-1}\right)$ & $\mathrm{Pb}\left(\mathrm{mg} \mathrm{kg}^{-1}\right)$ \\
\hline A (Jahad kashavarz habibabad) & $7.29 \pm 4.69^{\mathrm{A}}$ & $1.90 \pm 0.34^{\mathrm{AB}}$ \\
B (Nazdaneh) & $7.04 \pm 9.05^{\mathrm{A}}$ & $1.50 \pm 1.21^{\mathrm{AB}}$ \\
C (Biyabanzodaye shargh) & $2.87 \pm 0.78^{\mathrm{A}}$ & $1.33 \pm 0.84^{\mathrm{AB}}$ \\
D (Sepahan morg komsheche) & $7.77 \pm 8.56^{\mathrm{A}}$ & $1.76 \pm 0.58^{\mathrm{AB}}$ \\
E (Khorasgan University) & $29.66 \pm 26.63^{\mathrm{A}}$ & $2.89 \pm 1.16^{\mathrm{A}}$ \\
F (Shahrak sanati jey) & $26.71 \pm 31.45^{\mathrm{A}}$ & $2.07 \pm 0.50^{\mathrm{AB}}$ \\
G (Gavdari) & $3.02 \pm 2.77^{\mathrm{A}}$ & $1.83 \pm 1.17^{\mathrm{AB}}$ \\
H (Masjed aliabadchi) & $1.94 \pm 1.90^{\mathrm{A}}$ & $1.34 \pm 0.75^{\mathrm{AB}}$ \\
I (Dehyari mehdiabad) & $2.83 \pm 1.07^{\mathrm{A}}$ & $0.98 \pm 0.24^{\mathrm{B}}$ \\
\hline
\end{tabular}

was a significant difference in $\mathrm{Pb}$ concentration in the winter compared with the summer $(\mathrm{P}<0.05)$ (Table III).

Table III. Comparison of mean values of heavy metals in different seasons.

\begin{tabular}{ccc}
\hline Heavy metal & DF & F Value \\
\hline $\mathrm{Pb}$ & 2 & $6.89^{* *}$ \\
$\mathrm{Zn}$ & 2 & $1.69^{\text {N.S }}$ \\
\hline
\end{tabular}

\subsection{Seasonal and spatial pattern and dust deposition rate (DDR)}

The Variance analysis of three-month DDRs for each season from nine sampling sites is reported as the mean DDR for each season. There was a statistically significant difference between mean DDR values in summer compared with the other seasons. The mean DDR winter value was $0.7 \pm 0.1$ ton $\mathrm{km}^{-2}$ month ${ }^{-1}$ while the corresponding value in summer was $40.8 \pm$ 0.1 ton $\mathrm{km}^{-2}$ month $^{-1}$, the lowest and highest values, respectively. (Table IV).

\subsection{Seasonal dust deposition rate}

In the winter, the highest and the lowest values of seasonal DDR were respectively reported for Nazdaneh $\left(11.53 \pm 0.1^{\mathrm{A}}\right)$ ton $\mathrm{km}^{-2}$ season $^{-1}$, an area almost in the center of Segzi Desert, and dairy farm $\left(0.70 \pm 0.1^{\mathrm{H}}\right)$ ton $\mathrm{km}^{-2}$ season ${ }^{-1}$, which is an area around which a lot of farms exist.

In the spring, the highest rates of seasonal dust deposition were reported in Jay Industrial Zone $\left(27.00 \pm 0.1^{\mathrm{A}}\right)$, followed by Nazdaneh $\left(11.90 \pm 0.1^{\mathrm{B}}\right)$ ton $\mathrm{km}^{-2}$ season ${ }^{-1}$, and the lowest rate was recorded for Khorasgan University $\left(3.90 \pm 0.1^{\mathrm{A}}\right)$ ton $\mathrm{km}^{-2}$ season $^{-1}$, the furthest area to Segzi Desert.

In the summer, the highest seasonal dust deposition rate was reported in Jay Industrial Zone (40.80 $\left.\pm 0.1^{\mathrm{A}}\right)$, followed by Nazdaneh $\left(17.20 \pm 0.1^{\mathrm{B}}\right)$ ton $\mathrm{km}^{-2}$ season ${ }^{-1}$, and the lowest deposition rate was recorded in Khorasgan University $\left(5.30 \pm 0.1^{\mathrm{H}}\right)$ ton $\mathrm{km}^{-2}$ season $^{-1}$ (Table V).

\section{Discussion}

The study of climatic characteristics in the region is useful to explain, to a large extent, the temporal distribution of DDR in different months. Al-Harbi (2013) investigated the total monthly dust fallout in Shuwaikh City, Kuwait and reported the highest DDR in June and August due to low humidity and dusty winds. That study argued that weather conditions, especially wind speed and direction have an important role in temporal variations of dust fallout. Likewise, in the present study, the highest DDR was recorded in the summer.

The correlation between the prevailing wind direction from the east and northeast in May, June, July and August with the highest DDR in these months is evidence in support of the hypothesis which states that the major source of dust in Isfahan originates from eastern and northeastern desert regions and Segzi Plain, and that prevailing northeasterlies and easterlies are responsible for the transport of dust particles. An increase in wind speed results in an increase in DDR. Moreover, it seems that low humidity and lack of rainfall in those months is another factor increasing DDR. Increase in relative 
Table V. Mean comparison of seasonal deposition rate.

\begin{tabular}{lcc}
\hline Season & DF & F Value \\
\hline Winter & 8 & $3218.84^{* *}$ \\
Spring & 8 & $13887.8^{* *}$ \\
Summer & 8 & $37470.3^{* *}$ \\
\hline
\end{tabular}

humidity could result in the adhesion of particles in dust-producing regions, and rainfall is a major sink of particles, leading to decreased dust concentration. Furthermore, rainfall affects soil humidity and vegetation as two important factors in decreasing dust sources and ambient concentration.

Ziyaee et al. (2018) investigate the effect of weather and topographic conditions on spatial and temporal variations of dust, in Razavi Khorasan Province, in northeastern Iran. Atmospheric dust samples were collected monthly from May 2014 to April 2015. The lowest and highest dust fallout occurred in December and June, respectively. Dust fallout was modeled as a function of temperature, precipitation, relative humidity, wind speed and distance from source regions. The highest amount of rainfall was reported in March, and in January, February and March precipitation was reported to be 96 millimeters. The highest evaporation rate and the lowest relative humidity were also reported between June and September during which the lowest monthly precipitation and the highest temperature were observed. In contrast, the lowest amount of evaporation and the highest relative humidity were observed in the winter, i.e., December and March (Ziyaee et al., 2018). Similar findings were obtained in this study, as in summer lowest precipitation and relative humidity and highest evaporation and temperature, resulted in the highest DDR, while in the winter, with opposite climatic parameters, the lowest DDR was recorded.

In another study, dust samples were collected on a monthly basis for 15 years from 50 urban sites in Gansu Province, China, providing information on the modern DDR in Gobi Desert and Loess Plateau. Moreover, the study showed a positive correlation between DDR and dust events, and a negative correlation between DDR and precipitation (Ta et al., 2004). Similar correlations were observed in the present study. 
In other months, in spite of the anthropologic activities resulting in particulate matter production in Isfahan, a change in wind direction from the west and southwest leads to a decrease in the DDR. This could be indicative of the change in source or the effect of other meteorological parameters on the DDR. Although prevailing westerly winds have high speeds, they do not advect dust particles mainly because there are no desert sources. Since prevailing westerly winds blow in the cold seasons of the year, they lead to an increase in precipitation and relative humidity, which results in lower DDR. It is worth mentioning that determining the source of dust in Isfahan accurately and precisely requires further studies and more comprehensive laboratory analyses in the zone. Regarding the spatial variation of DDR in different seasons, it seems that the prevailing westerlies and southwesterlies in winter, higher relative humidity and an increase in soil particle adhesion, result in the growth of particle size and, therefore, particles deposited closer to the source. As a result, the highest DDR was observed in the eastern and central areas of the city. However, within the three months of the summer, the prevailing easterly and northeasterly winds carried dry and smaller dust particles from the eastern part of the city and, causing dust particles to deposit in the western areas of the city.

The concentrations of $\mathrm{Zn}$ and $\mathrm{Pb}$ showed variation between winter, spring and summer due to climatic conditions. Most of the polluting industries are located in the western part of the city and with prevailing westerly winds during winter, it can be the reason of higher concentration of heavy metals in colder seasons compared with summer. However, it should be mentioned that some industrial sites in the eastern part of the city also cause considerable pollution. Moreover, meteorological conditions associated with low temperature and inversion can remarkably affect the deposition rate of atmospheric pollutants. The use of fossil fuels as sources for heating in cold seasons and the pollution resulting from it further supports the high concentration of these heavy metals in cold seasons. All in all, anthropogenic activities are the main sources of pollution from heavy metals which is more evident in winter dust compared with summer dust.

The findings obtained from the following studies, in much the same way as the findings of the present study, indicate that anthropogenic activities are the main sources of heavy metals. Soleimani et al. (2018) analyzed the content of heavy metals in fine particulate matter $\left(\mathrm{PM}_{2.5}\right)$ in the atmospheric monitoring stations of Isfahan province in different seasons from March 2014 to March 2015. They attempted to identify the sources using principal component analysis (PCA), revealing that heavy metals mainly originate from fossil fuel combustion, abrasion of tires of vehicles, industrial activities such as those in iron and steel industries, and dust storms.

Mirzaei Aminiyan et al. (2017) investigated the sources, concentrations, spatial distribution and ecological risks of heavy metals $(\mathrm{Pb}, \mathrm{Ni}, \mathrm{Cr}, \mathrm{Cu}, \mathrm{Cd}$, As and $\mathrm{Zn}$ ) in road dust in Rafsanjan, Iran. The concentration of heavy metals in the road dust was higher than in the natural background, which was argued originated from such anthropogenic sources as copper mining plants, smelting sites, industrial and chemical activities, inappropriate use of chemical fertilizers and pesticides in farms, and heavy traffic (Mirzaei Aminiyan et al., 2017).

Doabi et al. (2017) collected 98 dust samples from urban and rural areas of Kermanshah province, Iran during the spring and summer of 2013. They analyzed the total concentration of heavy metals and the concentrations of $\mathrm{Zn}, \mathrm{Cu}, \mathrm{Ni}, \mathrm{Cr}, \mathrm{Mn}$, and Fe. Using correlation analysis and cluster and principal component analysis the study revealed that $\mathrm{Zn}$ and $\mathrm{Cu}$ originated mainly from traffic sources as well as industrial activities, supporting anthropogenic sources for heavy metals (Doabi et al., 2017).

Behrooz et al. (2017) analyzed total suspended particulates (TSP), particulate matter $\left(\mathrm{PM}_{10}\right.$ and $\mathrm{PM}_{2.5}$ ) together with soil samples taken from the dry lakebed located in Sistan basin, in southeastern Iran. The samples were collected from June to October, 2014. One of the major findings indicated that fuel combustion, heavy traffic, and industrial emissions are the most important anthropogenic sources of dust-borne heavy metals in Sistan.

Lin et al. (2016) collected samples from 23 sites in China during 12 months to characterize sources and health risks of heavy metals in the street dust. A total of 276 samples were collected and analyzed for $\mathrm{Cr}, \mathrm{Cu}, \mathrm{Mn}, \mathrm{Pb}, \mathrm{C}$ and $\mathrm{Zn}$. The results obtained from multivariate techniques (for example, Pearson correlation, hierarchical clustering and componential 
analysis) indicated that $\mathrm{Pb}$ and $\mathrm{Zn}$ originate from complicated sources; $\mathrm{Zn}$ could result from wear and tear of vehicle tires and corrosion of galvanized vehicle parts while transportation was the major cause of $\mathrm{Pb}$. Abbasi et al. (2018) also conclude that vehicular traffic and industrial emission are the major anthropogenic sources of heavy metal. The results found in the present study regarding heavy metals are in agreement with these other published studies.

\section{Conclusion}

To investigate seasonal and spatial changes in dust deposition rate (DDR) and the concentration of dustborne heavy metals in Isfahan and the neighboring areas in central Iran, dust samples were collected on a monthly basis from 21 December 2016. The significant statistical changes observed in seasonal DDR seem to be a response to changes in meteorological parameters. The maximum value of 40.8 ton $\mathrm{km}^{-2}$ month ${ }^{-1}$ was observed during summer, with high temperatures and easterly winds advecting dust from the desert. Higher precipitation, humidity and vegetation tend to suppress ambient dust in colder seasons. As a result, the minimum value of 0.7 ton $\mathrm{km}^{-2}$ month ${ }^{-1}$ dust was observed in winter.

Dust particles mainly deposit in the northern and eastern stretches of the area under investigation which are characterized with barren lands. Seasonal changes affected the concentrations of most of the dust-borne heavy metals; the lowest and highest concentrations were observed in the summer and winter, respectively. All of the metals were observed to have higher mean concentrations in dust samples compared with the background values in the soil samples.

Dust deposition rate in the whole area under study was higher in summer compared with other seasons. However, lower concentration of toxic metals in summer dust would suggest it would be less harmful. In contrast, the highest concentrations of toxic metals are reported in winter, responsible for adverse effects on health during this season.

Although industrial and traffic sources emit fixed amounts of heavy metals yearly, meteorological variations in the region lead to differences in pollution levels in different seasons. Therefore, to lessen the adverse effects of dust deposition in the region, it is necessary to take measures to reduce the concentra- tion of dust-borne heavy metals. This should be done more vigorously in winter when polluted air stagnant due to coldness and stability.

\section{References}

Abbasi S, Keshavarzi B, Moore F, Mahmoudi MR. 2018. Fractionation, source identification and risk assessment of potentially toxic elements in street dust of the most important center for petrochemical products Asaluyeh County, Iran. Environmental Earth Sciences 77: 1-19. https://doi.org/10.1007/s12665-018-7854-z

Abdul Wahab NA, Darus FM, Isa N, Sumari SM, Hanafi NF. 2012. Heavy metal concentration of settled surface dust in residential building. The Malaysian Journal of Analytical Sciences 161: 18-23.

Aghasi B, Jalalian A, Khademi H, Besalatpour A. 2019. Relationship between dust deposition rate and soil characteristics in an arid region of Iran. Atmósfera 32: 115-128 https://doi.org/10.20937/atm.2019.32.02.03

Al-Harbi M. 2013. Characteristics and composition of the falling dust in urban environment. Environmental Science and Technology 12: 641-652. https://doi. org/10.1007/s13762-013-0440-8

Behrooz DR, Esmaili-Sari A, Bahramifar N, Kaskaoutis DG, Saeb K, Rajaei F. 2017. Trace-element concentrations and water-soluble ions in size-segregated dust-borne and soil samples in Sistan, southeast Iran. Aeolian Research 25: 87-105. https://doi.org/10.1016/j. aeolia.2017.04.001

Doabi SA, Afyuni M, Karami M. 2017. Multivariate statistical analysis of heavy metals contamination in atmospheric dust of Kermanshah province, western Iran, during the spring and summer 2013. Geochemical Exploration 180: 61-70. https://doi.org/10.1016/j. gexplo.2017.06.007

Farkas O., Török A. 2019. Dust deposition, microscale flow and dispersion model of particulate matter, examples from the city center of Budapest. Quarterly Journal of the Hungarian Meteorological Service 123: 39-55. http://doi.org/10.28974/idojaras.2019.1.3

Han X, Lu X, Qinggeletu, Wu Y. 2017. Health Risks and Contamination Levels of Heavy Metals in Dusts from Parks and Squares of an Industrial City in Semi-Arid Area of China. Environmental Research and Public Health 148: 1-12. https://doi.org/10.3390/ ijerph14080886

Hojati S, Khademi H, Cano A, Landi A. 2012. Characteristics of dust deposited along a transect between central 
Iran and the Zagros Mountains. Catena 88: 27-36. https://doi.org/10.1016/j.catena.2011.09.002

Jahandari A. 2020. Pollution status and human health risk assessments of selected heavy metals in urban dust of 16 cities in Iran. Environmental Science and Pollution Research 27: 23094-23107. https://doi.org/10.1007/ s11356-020-08585-8

Jalali M, Zare M J, Brahmi A, Barijani N, Mahjub H. Analysis of Endogenous Alkanes and Aldehydes in the Exhaled Breath of Workers Exposed to Silica Containing Dust . johe. 2015; 1 (4) :19-29

Kidak R. 2017. Seasonal Assessment of Heavy Metal Pollution in Street Dust of Nicosia City in North Cyprus. Sustainable Development 64: 126-136. https://doi. org/10.14207/ejsd.2017.v6n4p126

Li F, Zhang J, Huang J, Huang D, Yang J, Song Y, Zeng G. 2016. Heavy metals in road dust from Xiandao District, Changsha City, China: characteristics, health risk assessment, and integrated source identification. Environ Sci Pollut Res 23: 13100-13113. https://doi. org/10.1007/s11356-016-6458-y

Lin M, Gui H, Wang Y, Peng W. 2017. Pollution characteristics, source apportionment, and health risk of heavy metals in street dust of Suzhou, China. Environmental Science and Pollution Research 24: 1987-1998. https:// doi.org/10.1007/s11356-016-7934-0

Malakootian M, Ghiasseddin M, Akbari H, Jaafarzadeh-Haghighi Fard N. 2013. Urban Dust Fall Concentration and its Properties in Kerman City, Iran. Health Scope 1(4): 195-201. https://doi.org/10.17795/ jhealthscope- 8507

Menéndez I, Díaz-Hernández JL, Mangas J, Alonso I, Sánchez-Soto PJ. 2007. Airborne dust accumulation and soil development in the North-East sector of Gran Canaria (Canary Islands, Spain). Journal of Arid Environments 71: 57-81. https://doi.org/10.1016/j. jaridenv.2007.03.011

Mirzaei Aminiyan M, Baalousha M, Mousavi R, Mirzaei Aminiyan F, Hosseini H, Heydariyan A. 2018. The ecological risk, source identification, and pollution assessment of heavy metals in road dust: a case study in Rafsanjan, SE Iran. Environmental Science and Pollution Research 25(14): 13382-13395. https://doi. org/10.1007/s11356-017-8539-y
Norouzi S, Khademi H, Ayoubi S, Cano AF, Acosta JA. 2017. Seasonal and spatial variations in dust deposition rate and concentrations of dust-borne heavy metals, a case study from Isfahan, central Iran. Atmospheric Pollution Research 8: 686-699. https://doi.org/10.1016/j. apr.2016.12.015

Risser JA, Baker DE, 1990. Testing soils for toxic metals. In: Westerman, R.L. (Ed.), Soil Testing and Plant Analysis. Soil Science Society of America, Inc, Madison. WI, pp. 275-298.

Soleimani M, Amini N, Sadeghian B, Wang D, Fang L. 2018. Heavy metals and their source identification in particulate matter (PM2.5) in Isfahan City, Iran, Journal of Environmental Sciences 72: 166-175. https://doi. org $/ 10.1016 /$ j.jes.2018.01.002

Ta W, Xiao H, Qu J, Xiao H, Yang G, Wang T, Zhang X. 2004. Measurements of dust deposition in Gansu Province, China, 1986-2000. Geomorphology 57: 4151. https://doi.org/10.1016/S0169-555X(03)00082-5

Wan D, Han Z, Yang J, Yang G, Liu X. 2016. Heavy Metal Pollution in Settled Dust Associated with Different Urban Functional Areas in a Heavily Air-Polluted. International Journal of Environmental Research and Public Health 13: 1-13. https://doi.org/10.3390/ ijerph13111119

Zgłobicki W, Telecka M, Skupiński S. 2019. Assessment of short-term changes in street dust pollution with heavy metals in Lublin E Poland-levels, sources and risks. Environmental Science and Pollution Research Int 26: 35049-35060. https://doi.org/10.1007/s11356019-06496-x

Ziyaee A, Karimi A, Hirmas D, Kehl M, Lakzian A, Khademi H, David B, Mechem. DB. 2018. Spatial and temporal variations of airborne dust fallout in Khorasan Razavi Province, Northeastern Iran. Geoderma 326: 42-55. https://doi.org/10.1016/j.geoderma.2018.04.010

Zhang X, Sharratt B, Chen X, Wang Z, Liu L, Guo Y, Li J, Chen H, Yang W. 2017. Dust deposition and ambient PM10 concentration in northwest China: spatial and temporal variability. Atmospheric Chemistry and Physics 17: 1699-1711. https://doi.org/10.5194/acp17-1699-2017 